\title{
New or little-known species of the genus Eustra Schmidt-Göbel, 1846 (Coleoptera: Carabidae: Ozaenini)
}

\author{
Новые и малоизвестные виды Eustra Schmidt-Göbel, 1846 \\ (Coleoptera: Carabidae: Ozaenini)
}

\author{
D.N. Fedorenko \\ A.H. Федоренко
}

\begin{abstract}
A.N. Severtsov Institute of Ecology and Evolution, Leninsky pr. 33, Moscow 119071, Russia.
Институт проблем экологии и эволюции им. А.Н. Северцова, Российская Академия наук, Ленинский пр-т 33, Москва 119071 , Россия. E-mail: dmitri-fedorenko@yandex.ru
\end{abstract}

KEY WORDS: Coleoptera, Carabidae, Ozaenini, Eustra, new species, Vietnam, Oriental region.

КЛЮЧЕВЫЕ СЛОВА: Coleoptera, Carabidae, Ozaenini, Eustra, новые виды, Вьетнам, Ориентальная область.

ABSTRACT. Eight non-cavernicolous species of the genus Eustra Schmidt-Göbel, 1846 are reviewed, including four new species and one new subspecies described: E. cariniceps sp.n., E. posteroguttata sp.n., E. dalatensis sp.n., and E. nageli subglabra ssp.n. from Vietnam, and E. parallela sp.n. from Borneo. Eustra matanga matanga is recorded in the island of Bali. Key to the Vietnamese species is provided.

РЕЗЮМЕ. Дан обзор 8 открыто живущих видов рода Eustra Schmidt-Göbel, 1846 с описанием 4 новых видов и 1 подвида: E. cariniceps sp.n., E. posteroguttata sp.n., E. dalatensis sp.n. и E. nageli subglabra ssp.n. из Вьетнама и E. parallela sp.n. с Борнео. Eustra matanga matanga указан с о-ва Бали. Составлена таблица для определения Вьетнамских видов.

\section{Introduction}

The Oriental genus Eustra Schmidt-Göbel, 1846, Ozaenini, includes 26 species. Most of them are known to live under bark of dead trees and in rotten wood and the remaining seven are cavernicolous. Free-living species are largely small-sized and very similar in appearance, for which reason the genus has long been considered as oligotypic [Bates, 1892; Andrewes, 1919, 1929; Bänninger, 1927], comprised of a few species in addition to the widespread Oriental species E. plagiata Schmidt-Göbel, 1846. Several new species were described later [Bänninger, 1949; Ueno, 1964, 1981; Deuve, 1986, 1996, 2002, 2005]. Deuve [2001] revised the genus and contributed many new taxa to it. He mainly focused on the morphology of the genus, leaving all reviewed species very briefly described or re-described. The larva of Eustra was discovered soon [Moore et al., 2011], followed by discovery of a few new species and re-discovery of some little-known ones in Sulawesi [Faille, 2010] and China [Terada et al., 2013; Gueorguiev, 2014; Nagel, 2018; Song et al., 2018].

In this paper we treat six of totally seven species of the genus, recorded in Vietnam, leaving the cavernicolous species E. honchongensis Deuve, 1996 from southern Vietnam beyond the scope. Out of the species reviewed, new four are described and two re-described. Besides, one new species is described from Borneo and E. matanga matanga Andrewes, 1919 is recorded in the island of Bali. The bulk of material was collected during several field trips sponsored by the Russia-Vietnam Tropical Center.

Acronyms used are as follows: MNHM - Museum national d'Histoire naturelle, Paris; MPSU — collection of the Moscow Pedagogical State University; SIEE - the author's reference collection at A.N. Severtsov Institute of Ecology \& Evolution, Russian Academy of Sciences, Moscow; ZMMU - Zoological Museum of the Moscow State University.

The following parameters were analyzed: $\mathrm{BL}$ maximum body length measured between apices of closed mandibles and apex of elytra; EL — maximum length of elytron, measured between apex and highest point of base; EW - maximum width of elytra; HW width of head across eyes; PA — width of pronotum between apical angles; PB — width of pronotum between basal angles; PL - length of pronotum along median line; PLw - distance between apex and level of maximum width of pronotum, measured along mid-line;

How to cite this article: Fedorenko D.N. 2019. New or little-known species of the genus Eustra Schmidt-Göbel, 1846 (Coleoptera: Carabidae: Ozaenini)// Russian Entomol. J. Vol.28. No.1. P.15-16. doi: 10.15298/rusentj.28.1.02 
PW - maximum width of pronotum. Tarsal formula $(\mathrm{TF}=\mathrm{LT} 1 / \mathrm{LT} 5: \mathrm{LT} 2-4 / \mathrm{LT} 5)$ is used for meso- $(\mathrm{TF} 2)$ and metatarsi (TF3); LTm - length of respective tarsomere(s), $\mathbf{m}=1,2$ to 4 combined, or 5 .

Measurements were taken using an eyepiece micrometer, to two decimal places. The number of specimens measured (n) is only given for the first ratio in the description. All labels are printed, unless otherwise indicated. Data on labels of type specimens are in quotes.

\section{Results}

\section{Genus Eustra Schmidt-Göbel, 1846}

Schmidt-Göbel, 1846: 65; Chaudoir, 1854: 309; 1868: 71; Andrewes, 1919: 295, 299; 1929: 163, 167; Bänninger, 1927: 189, 206; Jeannel, 1946: 48; Stork, 1985: 1121, 1123; Deuve, 2001: 547-578; Moore et al., 2011: 63-82 (larva). typy).

Type species: Eustra plagiata Schmidt-Göbel, 1846 (by mono-

REDESCRIPTION. Body (Figs 1-6) macropterous, small, BL ca 2.5-4 mm in general, shiny or slightly dull, and rather pale, yellow or pale brown; elytra bimaculate, i.e., each with a darker, subquadrate, submedian macula. Dorsal microsculpture meshed, isodiametric, very superficial to obliterate; elytra laterally with aciculate microsculpture consisting of dense microscopic tubercles. Body appendages and underside rather densely pubescent; dorsal pubescence sparser, its density depends on head, pronotum or elytra, leaving elytral submarginal area glabrous; propleura generally smooth.

Head medium-sized, more or less constricted behind eyes, without fixed supra-ocular setae. Eyes round in lateral view, small and convex; genae distinct, oblique, neither toothed nor embracing eyes from behind. A well-developed ocular ridge running around and at a distance from eye; the ridge conspicuously edged anteroventrally, separating gena from maxillary fissure; dorsally it consisting of supra-antennal carina anteriorly and supra-ocular carina behind, the former running just inside the latter, with a strigose area mostly substituted for both at anterior margin of eye. Frontal foveae missing. Clypeus bisetose on each side, slightly transverse, subquadrate, gently sinuate apically; frontoclypeal suture mostly subsinuate. Labrum long trapezoidal, almost triangular, with sides straight to subsinuate and converging much apicad; apex rounded to truncate, tuberculate or crenulate, with eight close setae along apical margin and one preapical seta on each side of inner pair of setae; without or with a subtle emargination on each side of two median setae. Antennae rather short, moniliform, entirely pubescent; pilosity on antennomeres 1-4 similar to that on the rest. Scape globular, short, with or without dorsal seta, pedicel eccentrically articulated. Antennomeres 5-10 subglobose and increasingly, slightly to moderately, transverse, antennomere 11 parallel-sided, twice as long as wide and as long as antennomeres 8-10 combined.

Mandibles moderately long, scrobe with 0-2 setae along ventral ridge; terebral tooth small, retinacular ridge large, bifid, basal retinacular tooth triangular, blunt, without narrow basal extension. Mentum anteriorly bisetose, with vestigial median tooth; ligula subquadrate, quadrisetose, paraglossae adnate vestigial. Submentum quadrisetose, gula welldeveloped, moderately wide basally, almost indistinct at submentum. Maxillary cardo short, stipes bisetose. Terminal labial and maxillary palpomere fusiform, maxillary one twice as wide as penultimate palpomere. Penultimate labial palpomere with two very close setae.

Pronotum cordate, more or less transverse, broadest 1/3$1 / 5$ from apex. Base slightly narrower than apex, truncate, strongly and abruptly oblique on sides; basal angles sharp, obtuse to right. Apex deeply sinuate or subtruncate medially, apical angles acute and porrect. Sides rounded, subsinuate just behind apical angles and straight to sinuate before basal ones. Disc convex, lateral margin rather widely explanate and finely beaded, more or less reflexed basally; lateral edge setulose and tuberculate or crenulate to smooth. Basal foveae round and deep, occupying basal third, median line fine yet deep, basal transverse impression quite transverse and fairly deep, apical transverse impression less so.

Elytra estriate, wide, convex, broadest behind middle, with sides more or less rounded and diverging slightly apicad, more rounded behind humeri, obliquely truncate posteriorly; apices rounded separately each; lateral half of each elytron flattened and longitudinally impressed in third fourth to middle third. Base distinctly wider than that of pronotum, basal margin slightly oblique from humeri to mesothoracic peduncle; humeri prominent, with blunt or rounded apices. Basal ridge fine at humerus, vestigial inside; lateral reflexed margin narrow, interrupted before preapical plica; lateral edge setulose and almost indistinctly serrulate, sometimes ( $E$. nageli subglabra ssp.n.) smooth and nearly glabrous. Epipleura totally reduced behind preapical plica. Dorsum densely tuberculate and pilose, except for a smooth and glabrous submarginal area in middle third; pilosity dense to sparse, moderately long to very short. Fixed dorsal setae, basal or discal, missing; submarginal umbilical seta series (USS) continuous, consisting of larger setigerous pores, about ten (9-13) in basal $2 / 3$ and five on a level with and behind preapical plica, the anterior and posterior pore groups being connected by an oblique row of 3-7, mostly 4-5, smaller setigerous pores. - Anterior setigerous pores increased to 11-13 in number are due to the presence of a few minute pores additional to larger ten.

Underside: mesocoxae separate and slightly projecting, with ventral intercoxal bridge, chiefly posterior process of mesoventrite, totally reduced, leaving mesocoxal cavities shallow, more so mesally, and apodemal pits of mesofurca (mesendosternite) exposed; anterior metaventral process either somewhat pointed, tuberculate and projecting (E. cariniceps sp.n.) or apically blunt to truncate, not or barely projecting (the other congeners reviewed). Metacoxae separate. Abdominal sternites transversely sulcate at bases (which character is hardly traceable because of the sternites telescoped), with obligatory setae hardly separable from dense ventral pubescence if at all (four or more longer setae present closer to apical margin), sternite VII mostly bisetose on each side.

Legs. Chetome obscured by dense, longer and shorter, pilosity. Meso- and metatarsomere 1 long, as long as respective tarsomeres 2-4 combined, usually slightly to conspicuously longer than tarsomere 5. Protarsomeres 1-3 ventroapically rounded and setose; protarsomeres 1-2 barely dilated, with ventral pad, in male.

Aedeagus as in Figs 7-46; right paramere narrow, longer to shorter than left one; right paramere more or less densely setose, left paramere glabrous. Internal sac mostly with a cluster of $\mathrm{ca} 5-7$, strong, spiniform, radiating apical sclerites.

Female genitalia and reproductive tract. Gonocoxae entire, membranous and densely pubescent, widely separated by a round sclerotized part of bursa copulatrix; helminthoid sclerite well-developed. 
DIAGNOSIS. The genus is very distinctive within Ozaenini in many points (see also 'Comments' to the genus) Very small body size and pale brown ground-colour, combined with fusiform terminal palpomeres, separate Eustra and Dhanya Andrewes, 1919 from the other ozaenines. The two genera are otherwise very distinctive. Specifically, Eustra is readily distinguishable from Dhanya in having mesocoxae conspicuously separated (vs. contiguous) and propleural pits missing (well-developed propleural pits are autapomorphy of Dhanya within Ozaenini). The other differences of Eustra from Dhanya are many: ocular ridge well-developed throughout or nearly so ( $v s$. indistinct posteriorly), clypeus transversely subquadrate and bisetose on each side ( $v s$. long hexagonal and unisetose on each side), antennal scape globulose ( $v s$. short subcylindric), antennomere 11 much longer, labrum trapezoidal (vs. subquadrate), mandibles mediumsized and incurved ( $v s$. large and almost straight), mandibular scrobe with several setae in general ( $v s$. asetose), gula welldeveloped ( $v s$. totally reduced), submentum bisetose ( $v s$. unisetose), mentum tooth indistinct (vs. well-developed), maxillary stipes bisetose ( $v s$. unisetose), pronotal lateral edge setulose and crenulate or tuberculate (vs. smooth, with 3-4 subequally spaced setae inside), elytral epipleura missing apically ( $v s$. entire), elytral discal setae missing ( $v s$. multiple
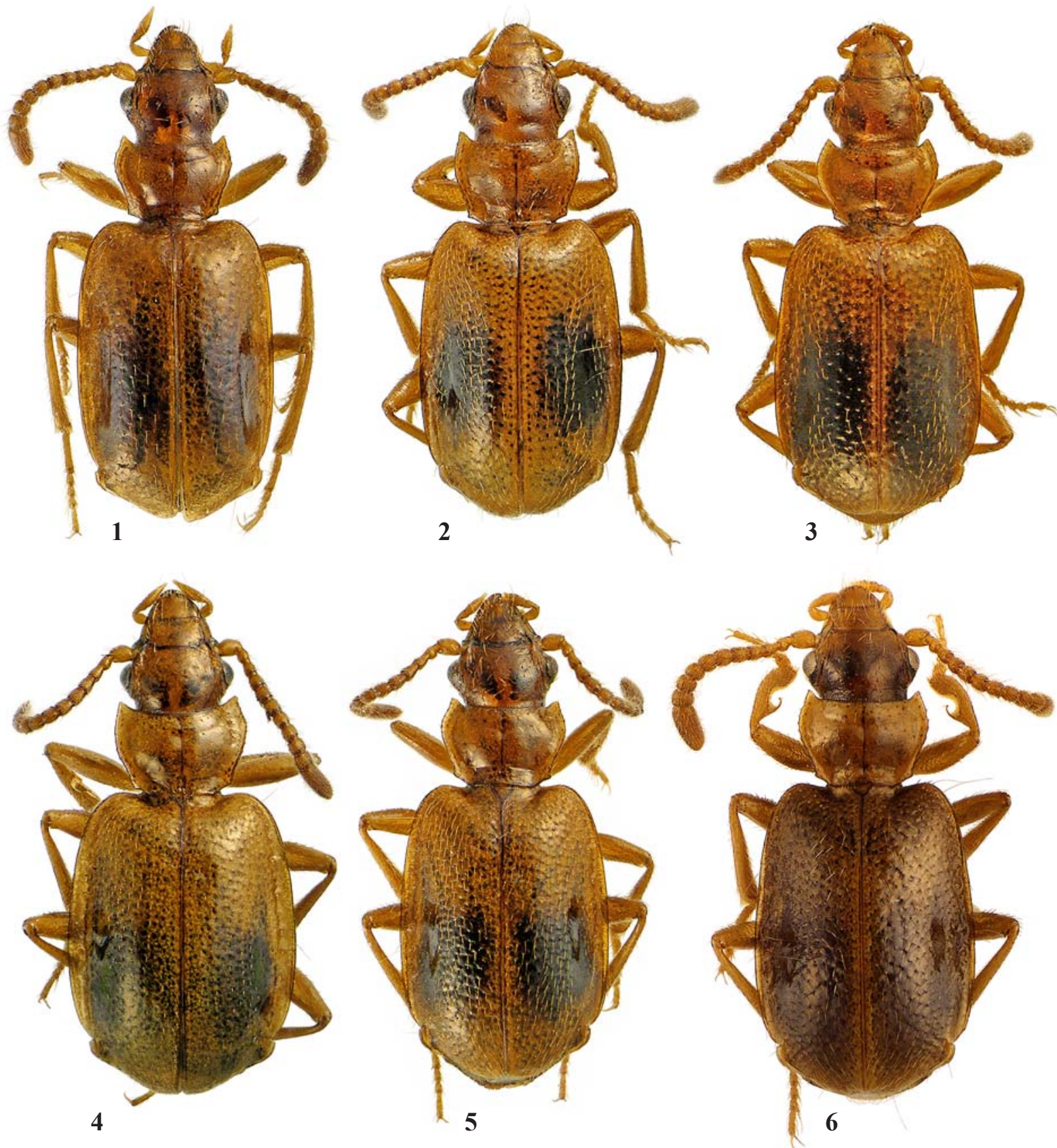

Figs 1-6. Eustra spp., dorsal habitus: $1-$ E. parallela sp.n.; $2-$ E. cariniceps sp.n.; $3-$ E. posteroguttata sp.n.; $4-$ E. nageli subglabra ssp.n.; $5-E$. dalatensis sp.n.; $6-$ E. csikii.

Рис. 1-6. Eustra spp., габитус дорзально: $1-$ E. parallela sp.n.; $2-$ E. cariniceps sp.n.; $3-$ E. posteroguttata sp.n.; $4-$ E. nageli subglabra ssp.n.; $5-$ E. dalatensis sp.n.; $6-$ E. csikii. 
in sites of intervals 3 and 5), protarsomeres 1-3 ventroapically rounded (vs. toothed at each apical angle), protarsomeres 1 and 2 slightly dilated and with ventral pad in male (vs. not dilated and without ventral pad), mesotarsomere 1 longer, as long as mesotarsomeres 2-4 combined ( $v s$. as long as those 2 and 3 combined), metatarsomere 1 much longer than ( $v s$. as long as) metatarsomere 5, abdominal sternite VII membranous yet entire apically ( $v s$. well sclerotized, being sinuate in female in addition), with 2 apical setae on each side in general ( $v s$. 3-4 setae on each side), female gonocoxite IX membranous ( $v s$. well sclerotized). Finally, the genus has ventral structure of pterothorax unique within Adephaga.

DISTRIBUTION. The range extends throughout the Oriental region from Sri Lanka, southern India and Nepal, through Indochina to Taiwan, southern China, southern Japan, the Sunda Isles and the Philippines, including also adjacent parts of Palearctic East Asia in eastern China, Korea and Japan.

HABITATS AND HABITS. The members of the genus are silvicolous or cavernicolous. Silvicoles were captured at elevations ranging between 60 and 1,900 $\mathrm{m}$ a.s.l. Many of them are known from one to a few specimens only and rare in collections. On the other hand, most species taken by me in Vietnam are not uncommon lowland and piedmont forest-dwellers. Great majority of the specimens were captured by hands under bark of larger dead trees, standing or fallen, or under tree fragments on the ground (E. csikii) at elevations below $800 \mathrm{~m}$ a.s.l. The species were found to be associated with ants and/or termites, with two or three of them sometimes sharing their habitats with one another and often also with such carabids as Dhanya bioculata Andrewes, 1919 (Ozaenini), Perigona spp. (Perigonini), and Morion spp. (Morionini).

COMMENTS. The above redescription only concerns non-cavernicolous species reviewed below.

Ventral pterothoracic structure of Eustra is worthy of special mention. Even though this pattern looks very primitive, it with no doubt has emerged from much more complex structure in course of evolution. This latter groundplan is peculiar to nearly all Adephaga and includes almost internally contiguous mesocoxae, ventrally bridged with posterior process of mesoventrite and anterior process of metaventrite. These two cover mesal parts of the coxae ventrally, with apex of the latter process being superimposed on the former, to make mesocoxal cavities well separated in ventral view. Omophron Bonelli, 1810 has widely separated mesocoxal cavities and distinctly separated mesocoxae, which is certainly due to its nearly circular body, and the other deviations from the groundplan are only observed within Paussinae, including Ozaenini. Some of them, e.g., Pseudozaena Laporte, 1834, match well the groundplan, except only that the mesoventrite posterior to the mesothoracic peduncle is short. Many other Ozaenini demonstrate gradual reduction of the mesocoxal bridge in width and usually also in depth, as the mesocoxae become increasingly projecting and mesocoxal cavities increasingly shallow. Ventral pterothoracic structure of Eustra has most probably evolved from separating between contiguous mesocoxae (Pachyteles Perty, 1830, Dhanya Andrewes, 1919) following or, less likely, followed by totally reduced intercoxal bridge.

Neotropical Ozaenini and the remaining Ozaenini + Metriini are sister-groups based on molecular evidence [Moore, 2008], but Eustra and Dhanya were out of that analysis. While differences between Eustra and Dhanya are many, both share at least five derived character states: metatarsomere 1 as long as to much longer ( $v s$. much shorter) than metatarsomere 5; terminal maxillary and labial palpomeres acuminate (vs. subtruncate to triangular); elytra with ( vs. without) aciculate microsculpture along sides; small body size; and contiguous (vs. separated) mesocoxae/ mesocoxal cavities as primary feature. These synapomorphies combined suggest closer relationships between Eustra and Dhanya than between either and the other Paleotropical Ozaenini, and $D$. mulu Stork, 1985 apparently fills morphological gap between the two genera with itself. It shares more characters with Eustra than with Dhanya, i.e., clypeus bisetose on each side anteriorly, mandibles medium-sized, scape globulose, pronotal lateral edge crenulate and pilose ( $v s$. smooth, with only $3-$ 4 lateral setae inside lateral edge), and meso- and metatarsal formula being similar: mesotarsi with tarsomere 1 about as long as tarsomere 5 while metatarsi with tarsomere 1 considerably longer than tarsomere 5 .

Dhanya is much like a very small Itamus Schmidt-Göbel, 1846 or Sphaerostylus Chaudoir, 1848, with which it shares many characters, including more or less derived ones, such as a fairly long hexagonal clypeus, gula totally reduced behind, large mandibles, and protarsomeres 1-3 with ventro-apical angles toothed or spinose at least posteriorly (externally). Based on this evidence, Eustra may be supposed to have evolved from Dhanya, and Dhanya from ancestors close to Itamus/Sphaerostylus or something. On the other hand, the gula is posteriorly distinct in Eustra, but much reduced throughout its length in the other Ozaenini examined for comparison, ranging from nearly indistinct in width in Pseudozaena orientalis (Klug, 1831) and Sphaerostylus sp., and through reduced to a suture posteriorly (Itamus, Pachyteles (s.lato) spp., Goniotropis spp., Scythropaussus sp.) to totally reduced (Ozaena spp., Platycerozaena sp., Dhanya) - this is inconsistent with the above hypothesis. Another character of Eustra, the presense of ventral protarsal pad in male accordingly means its secondary reduction in Dhanya and Itamus, partial to complete in the former while complete in the latter.

\section{Key to SPECIES OF EUSTRA OF VIETNAM}

1(12) Silvicolous, macropterous and macrophthalmic species; elytra mostly bimaculate.

2(11) Body unicoloured yellow to pale brown, except for elytra each with a darker spot.

3(10) Elytral pubescence dense and long, setae as long as or barely longer than distance between neighbouring two in longitudinal row. Body slender, EL/EW 1.31-1.45.

4(5) Head, especially vertex, very convex, neck constriction very deep. Pronotal lateral edge nearly smooth. Elytral spots large, mostly extending from $2 / 5$ to just before apex. - Southern and Central Vietnam

\section{E. posteroguttata sp.n.}

5(4) Head with vertex slightly convex to nearly flat, neck constriction shallow to deep. Pronotal lateral edge nearly smooth. Elytral spots either smaller or vague.

6(7) Elytral spot median in position; ocular ridge dorsally conspicuous, entire and black. Pronotum more rectangular than in the other species and transverse, PW/PL 1.471.60. BL 2.8-3.2 mm. - Southern and Central Vietnam. 1. E. cariniceps sp.n.

7(6) Combination of characters other than above.

8(9) Elytra vaguely infuscated on disc, without distinct spot; pronotum cordate and narrow, PW/PL 1.33. Body small, BL $2.95 \mathrm{~mm}$. - Northern Vietnam

$$
\text { 2. E. gomyi Deuve, } 2001
$$

9(8) Elytra each with a spot extending from middle to $2 / 5$ elytra; pronotum more transverse, PW/PL 1.50-1.57. Body larger, BL 3.5-3.7 mm. - Southern Vietnam ..... 4. E. dalatensis sp.n. 
10(3) Elytral pubescence moderately dense and very short, setae about half as long as distance between neighbouring two in longitudinal row. Body robust, EL/EW 1.26-1.31. Elytral spots small to indistinct, between middle and 3/4 elytra. Southern Vietnam ............. 6. E. nageli subglabra ssp.n.

11(2) Head dark brown to black, except for pale mouthparts, labrum, and clypeus; elytra dark brown, with suture, narrow lateral margin and apex, and basal third paler, reddish-brown to brown. Pronotal lateral edge tuberculate to denticulate. Elytra densely tuberculate-pubescent. 5. E. csikii Jedlička, 1968

12(1) Cavernicolous, apterous and microphthalmic species of uniformly pale brown colour. - Kien Kiang Province.

E. honchongensis Deuve, 1996

\section{Eustra cariniceps Fedorenko, sp.n.}

Figs 2, 22-23, 28, 33-34.

MATERIAL. Holotype $\sigma^{\top}$ (ZMMU) labelled: 'S Vietnam, N Dongnai [=Dong Nai] Pr[ovince]., Nam Cat Tien Nat. Park, Exped.Russ.-Vietnamese, Tropical Centre, 26.X.2004, leg. D.Fedo-

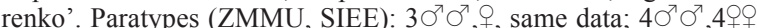
same data except 24-25.X.; $0^{7},+$, same data except 20-26.X.; + , same data except 26.XI.; $30^{\prime} 0^{\prime}, \rho^{\prime}$, ' Vietnam, Binh Phuoc Prov[ince]. Bu Gia Map Nat. Park, $12^{\circ} 11^{\prime} 37^{\prime \prime N} / 107^{\circ} 12^{\prime} 21^{\prime \prime} \mathrm{E}, \mathrm{h}=350-540 \mathrm{~m}$, 16-17.IV.2009, leg. D. Fedorenko'; $0^{7}, 2$, 9 , 'Vietnam, Gia Lai Province, $\sim 55 \mathrm{~km}$ ENE of Pleiku, $14^{\circ} 17^{\prime} 45^{\prime \prime} \mathrm{N} / 108^{\circ} 26^{\prime} 57^{\prime \prime} \mathrm{E}$, Kon Ka Kinh Natn. Park, h=600 m, 8-20.V.2017'.

DESCRIPTION. BL $2.8-3.2 \mathrm{~mm}$, body (Fig. 2) very shiny, pale brown, elytra each with a rounded to subquadrate median spot extending from $1 / 3$ to $3 / 4$ elytra; the spots distinctly separated along suture and reaching lateral margin or almost so. Dorsal microsculpture very superficial on labrum, clypeus and anterior part of frons, obliterate behind, including on pronotum and elytra, hardly traceable here and there along explanate pronotal margin; elytra with aciculate microsculpture outside glabrous submarginal area. Head and pronotum rather sparsely yet distinctly pubescent, elytra densely and evenly punctate-pubescent, setae as long as or barely longer than distance between neighbouring two in longitudinal row.

Head: vertex moderately convex, neck constriction shallow medially and deeper laterally. Supra-ocular carina mostly entire, sharp, black, and directly extended into supraantennal plates; genae slightly uneven, interrupted by ocular ridge. Frontoclypeal suture concave. Labrum apically evenly convex or with a median tubercle produced. Antennomeres 5-10 increasingly transverse, antennomere 10 distinctly transverse. Mandibular scrobe with $0-1$ seta.

Pronotum subcordate, almost square, half wider than long, PW/PL 1.47-1.60 (1.52, n=5), PW/HW 1.10-1.14 (1.12), broadest a third from apex, PLw/PL 0.23-0.31 (0.25, $\mathrm{n}=8$ ), sides distinctly sinuate in front of basal angles. Base barely narrower than apex, PB/PA 0.88-0.96 (0.94), its sides mostly subsinuate; apex subsinuate to truncate between acute and porrect apical angles; basal angles sharp, rectangular or subrectangular. Basal foveae large, deep, rounded, slightly oblong; each mostly with an impressed line at bottom, these lines running parallel behind basal transverse impression while strongly diverging before to extend into a more or less deep submarginal lines that almost reach apex. Explanate lateral margin narrow, more reflexed basally, rather widely explanate-reflexed in apical half in the case of a deeper submarginal line; lateral edge with 2-4 tubercles in basal half and minutely tuberculate to nearly smooth before. Basal bead fine to missing.

Elytra moderately long, EL/EW 1.36-1.44 (1.41, n=5), EW/PW 1.61-1.71 (1.66); base oblique towards peduncle, humeri subangulate and blunt, sides poorly rounded, nearly parallel. USS consisting of $10+3-7+5$ setae. Submarginal glabrous area large and glossy.

Legs. Mesotarsomere 1 as long as mesotarsomeres 2-4 combined and distinctly longer than mesotarsomere 5 , TF2 $1.16-1.40$ (1.27) : 1.17-1.40 (1.29), metatarsomere 1 distinctly longer than metatarsomeres $2-4$ combined and much longer than mesotarsomere 5, TF3 1.54-2.0 (1.73) : 1.43-1.67 (1.55).

Aedeagus (Figs 22-23, 28, 33-34) small; median lobe with widely rounded apex; right paramere shorter than left one, fairly wide, attenuated apicad, with apex truncate. Internal sac without apical sclerites.

DIAGNOSIS. Recognizable by the combination of body small and unicoloured, with dark elytral spots in medial position, elytra very shiny following no microsculpture, especially so over a fairly wide submarginal area, elytral pubescence dense and moderately long, labrum convex anteriorly, neck-constriction shallow medially, supraocular ridge conspicuous and dark, pronotal edge denticulate at least basally. Aedeagus is very similar to that of E. homyi Deuve, 2001, except for apex being widely rounded, with no preapical sinuation at right margin ( $v s$. wide yet slightly triangular, with a shallow sinuation).

DISTRIBUTION. Southern and Central Vietnam: Dong Nai, Binh Phuoc, and Gia Lai provinces.

NAME. Refers to the conspicuous supraocular carina.

HABITATS AND HABITS. As described for the genus.

\section{Eustra gomyi Deuve, 2001}

Deuve, 2001: 566 (Hoa Binh, northern Vietnam)

MATERIAL. Holotype O' (MNHN) labelled: 'HOLOTYPE', 'Hoa-Binh, Tonkin, A. de Cooman', 'Muséum Paris, Coll. Ch. ALLUAUD', 'Eustra, gomyi n. sp., Holotype [handwritten], Th. Deuve det. 1996'.

REDESCRIPTION. As the previous species except as follows: BL $2.95 \mathrm{~mm}$, body shiny yellow, elytral disc vaguely infuscated. Elytral microsculpture nearly indistinct except along sides.

Supra-ocular carina fine between the level of anterior margin of eye and gena, imperceptible before and behind; supra-antennal carina running just inside up to eye midlength.

Pronotum cordate, only a third wider than long, PW/PL $1.33, \mathrm{PW} / \mathrm{HW} 1.10$, broadest less than a third from apex, PLw/PL 0.29, sides subsinuate behind apical angles and before basal ones; base barely narrower than apex, PB/PA 0.94, truncate medially, its sides straight; basal angles obtuse and sharp. Lateral margin moderately explanate and slightly reflexed in apical half, narrowly explanate and more reflexed behind, still more so at basal angles; basal bead missing, almost indistinct laterally; lateral edge imperceptibly tuberculate, setulose at tubercles; median line, apical and basal impressions fine, latter two V- and inversely V-shaped, respectively. Basal foveae smooth, oblong and fairly deep, almost reaching middle, slightly diverging before basal transverse impression. Disc rather smooth.

Elytra: EL/EW 1.4, EW/PW 1.8 (both ratios are rough following widely unlocked elytra); base truncate, humeri rather widely rounded, and sides distinctly rounded; USS $9+4+5$. Antennae submoniliform, slender, barely wider at apex than at base, with antennomere 10 as long as wide.

DIAGNOSIS. Besides the slight difference in the shape of aedeagus, this species is distinctive from E. cariniceps sp.n. in having antennomere 10 as long as wide, pronotum cordate and distinctly longer, with sides subsinuate in front of obtuse basal angles, and sides of base straight.

DISTRIBUTION. Known from the type locality only.

HABITATS AND HABITS. No data. 
3. Eustra posteroguttata Fedorenko, sp.n.

Figs 3, 10-12, 27, 39-40.

MATERIAL. Holotype $\sigma^{\prime}$ (ZMMU) labelled: 'S Vietnam, N Dongnai [=Dong Nai] Pr[ovince]., Nam Cat Tien Nat. Park, Exped.Russ.-Vietnamese, Tropical Centre, 26.V.2005, leg. D.Fedo-

7

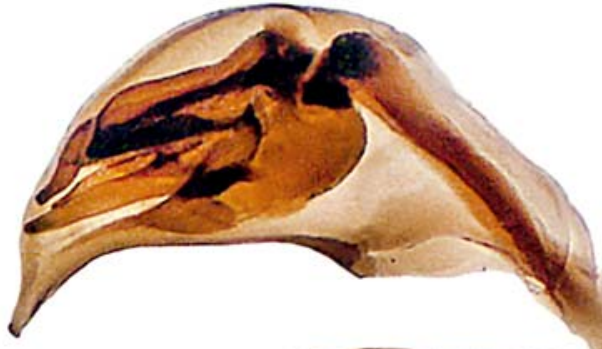

8
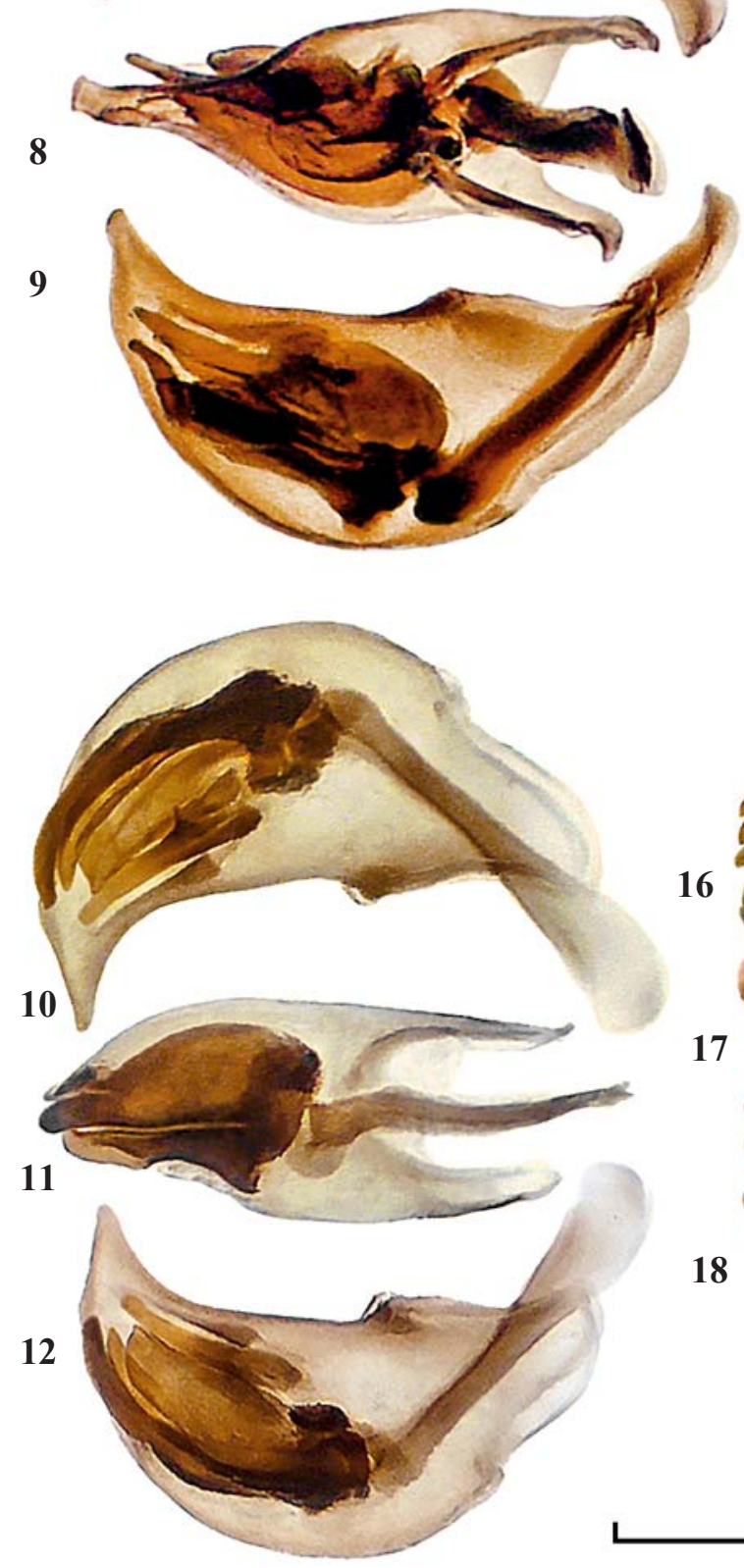

16

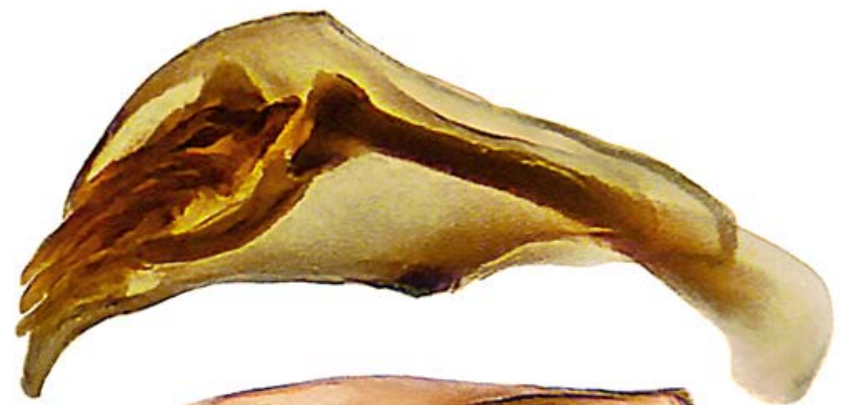

17

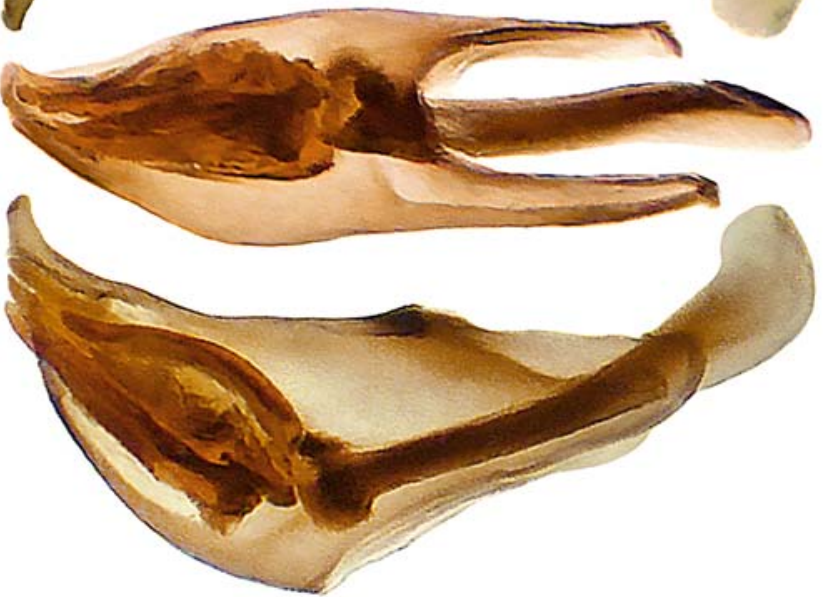

Figs 7-18. Median lobe of aedeagus: 7-9 - Eustra matanga matanga; 10-12-E. posteroguttata sp.n.; 13-15 - E. csikii; 16-18 - E. parallela sp.n.; 7, 10, 13,16 - right aspect; 8, 17 - ventral aspect; 9, 12, 15, 18 - left aspect; 11, 14 - dorsal aspect;. Scale bars: $0.5 \mathrm{~mm}$. Рис. 7-18. Средняя доля эдеагуса: 7-9 - Eustra matanga matanga; 10-12 - E. posteroguttata sp.n.; 13-15 - E. csikii; 16-18 E. parallela sp.n.; 7, 10, 13, 16 - справа; 8, 17 - снизу; 9, 12, 15, 18 - слева; 11,14 - сверху. Масштаб: 0.5 мм. 
$12^{\circ} 11^{\prime} 37^{\prime \prime} \mathrm{N} / 107^{\circ} 12^{\prime} 21^{\prime \prime} \mathrm{E}, \mathrm{h}=350-540 \mathrm{~m}, 16-17 . \mathrm{IV} .2009$, leg. D. Fedorenko'; $20^{7} 0^{\top}$, 2 29 , 'Vietnam, Gia Lai Province, $\sim 40 \mathrm{~km}$ ENE of Pleiku, $14^{\circ} 12^{\prime} 11^{\prime \prime} \mathrm{N} / 108^{\circ} 18^{\prime} 54^{\prime \prime} E$, Kon Ka Kinh Natn. Park, h=890 m, 9-22.V.2016, D.Fedorenko leg.'; 2 2 , , same locality, except for $\sim 55 \mathrm{~km}$ ENE of Pleiku, $14^{\circ} 18^{\prime} 22^{\prime \prime} \mathrm{N} / 108^{\circ} 26^{\prime} 23^{\prime \prime} \mathrm{E}, \ldots$ $\mathrm{h}=820 \mathrm{~m}, 8-20 . \mathrm{V} .2017$; $0^{\top}, 2$ 우, same data except $14^{\circ} 18^{\prime} 40^{\prime \prime} \mathrm{N} /$ $108^{\circ} 26^{\prime} 37^{\prime \prime} \mathrm{E}, \ldots, \mathrm{h}=730 \mathrm{~m}$.

DESCRIPTION. As E. cariniceps sp.n. except for the following: Body (Fig. 3) larger, BL 3.3-3.6 mm, shiny pale brown; elytral spots varying in size, being mostly large, extending from $2 / 5$ elytra to just before apex, rather narrowly separated along suture and well separated from lateral margin, sometimes either almost reaching lateral margin or smaller to totally reduced. Dorsal microsculpture distinct over labrum, slightly less so on clypeus and neck, highly superficial and hardly traceable on the rest of head and on pronotum; elytral microsculpture missing to hardly traceable (in some females); aciculate microsculpture occupying more extensive lateral region, often expanded onto submarginal glabrous area, sometimes traceable throughout elytra except along suture. Head sparsely pubescent, pronotum very sparsely so, elytra densely pubescent, more so toward bases; setigerous punctures tuberculate.

Head with very convex vertex due to neck constriction being very deep throughout. Very fine supra-ocular carina traceable above eye only, imperceptible to obliterate before and behind; genae subconvex to subangulate. Frontoclypeal suture slightly concave. Labrum apically convex or subtruncate. Mandibular scrobe bisetose.

Pronotum cordate, three fifths wider than long, PW/PL 1.50-1.66 (1.59, n=5), PW/HW 1.10-1.18 (1.13), broadest a fourth from apex, PLw/PL 0.24-0.30 $(0.27, \mathrm{n}=8)$, sides distinctly sinuate in front of basal angles, mostly straight or indistinctly sinuate just behind apical ones. Base slightly narrower than apex, PB/PA 0.82-0.89 (0.86), its sides mostly straight; apex sinuate; basal angles sharp, subrectangular to obtuse. Lateral margin narrowly explanate and strongly reflexed in basal half, more or less widely explanate before; lateral edge nearly smooth.

Elytra short, EL/EW 1.31-1.39 (1.33, n=5), EW/PW $1.66-1.81(1.75)$, broadest behind middle; base very gently oblique towards peduncle, humeri more rounded, sides diverging slightly apicad, nearly straight in middle third to two fourths. USS consisting of $10-13+4-5+5$ setae. Submarginal glabrous area mostly small.

Legs. TF2 1.17-1.27 (1.20) : 1.17-1.38 (1.25), TF3 $1.56-2.0(1.77): 1.25-1.72(1.48)$.

Aedeagus (Figs 10-12, 27, 39-40): median lobe with apex triangular and narrowly rounded; right paramere securiform, longer than the left one. Internal sac with large spiniform apical sclerites, including two, very large, dorsal ones.

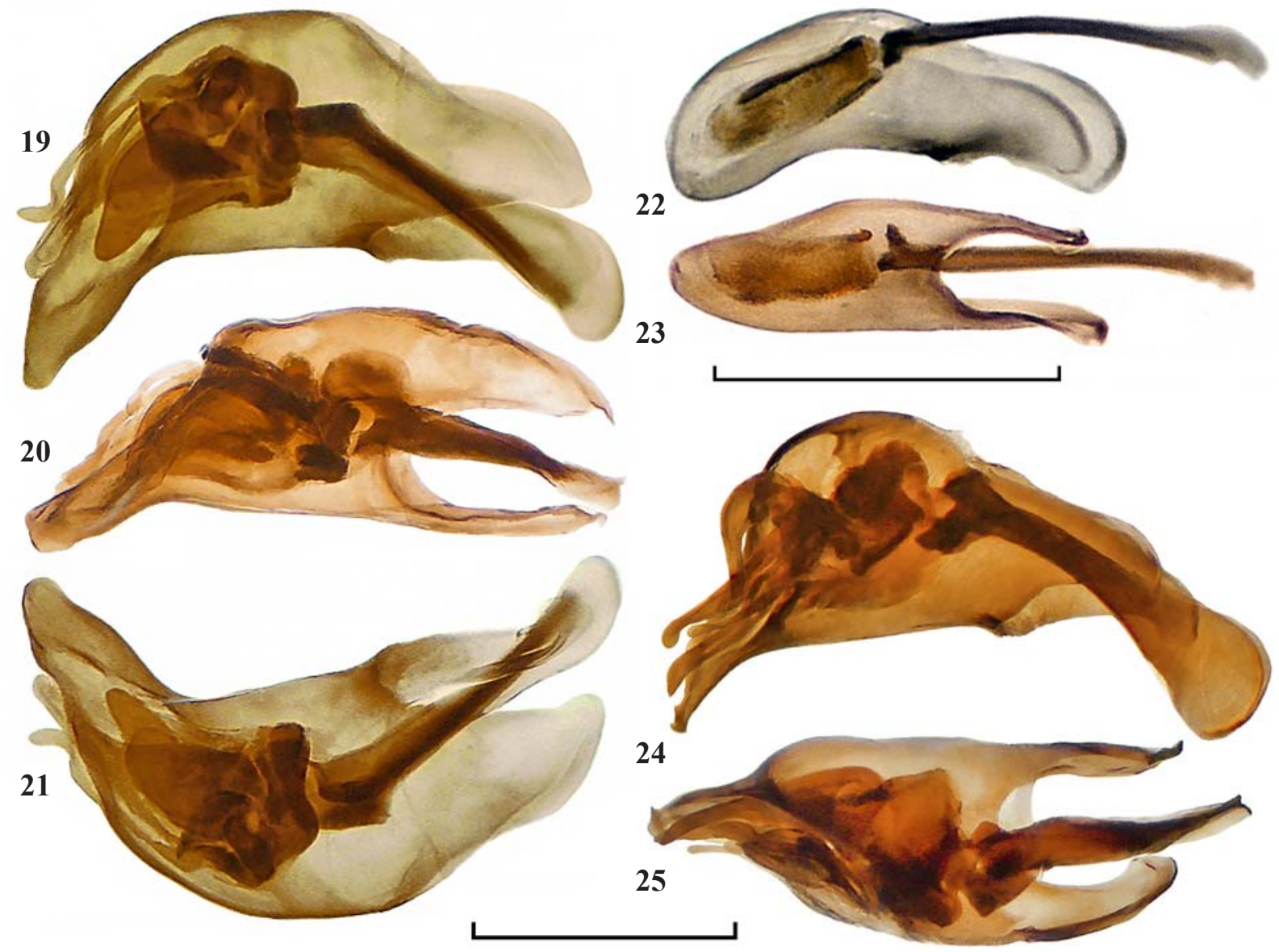

Figs 19-25. Median lobe of aedeagus: 19-21 - Eustra nageli subglabra ssp.n.; 22-23 - E. cariniceps sp.n.; 24-25 - E. dalatensis sp.n.; 19, 22, 24 - right aspect; 20, 23 - ventral aspect; 21 - left aspect; 25 - dorsal aspect. Scale bars: $0.5 \mathrm{~mm}$.

Рис. 19-25. Средняя доля эдеагуса: 19-21 - Eustra nageli subglabra ssp.n.; 22-23 - E. cariniceps sp.n.; 24-25 - E. dalatensis sp.n.; 19, 22, 24 - справа; 20, 23 - снизу; 21 - слева; 25 - сверху. Масштаб: 0.5 мм. 
DIAGNOSIS. Easily recognizable by the combination of very deep neck constriction, very convex vertex, nearly smooth lateral pronotal edge, and large elytral spots in almost postmedian position. This species is closely allied to E. matanga matanga. Both share very convex vertex before deep neck constriction and very similar aedeagus, but E. m. matanga has elytra longer, with ill-defined spot, labrum truncate, ocular ridge distinct, pronotal base barely wider relative to apex, internal sac of aedeagus with apical sclerites being different in shape, and right paramere slightly less rounded dorso-apically (Figs 7-9, 32, 35-36).

DISTRIBUTION. Southern and Central Vietnam: Dong Nai, Binh Phuoc, and Gia Lai provinces.

NAME. Refers to the position of the elytral spots.

HABITATS AND HABITS. As described for the genus.

\section{Eustra dalatensis Fedorenko, sp.n.}

Figs 5, 24-25, 29, 41-42.

MATERIAL. Holotype $\sigma^{7}$ (ZMMU) labelled: 'Vietnam, Dak Lak Prov[ince]., Chu Yang Sin Nat[io]n[al]. Park, $12^{\circ} 23^{\prime} 48^{\prime \prime} \mathrm{N}$ $108^{\circ} 20^{\prime} 59^{\prime \prime} \mathrm{E}$, upper flow of Krong Kmar riv[er], $\mathrm{h}=1000 \mathrm{~m}, 30$.III14.IV.2012, D.Fedorenko leg.' Paratype + (SIEE): 'S[outhern] Vietnam, Lam Dong Prov[ince]., Bi Doup — Nui Ba Nat[ure]. Res[erve]., env. Long Lanh, $12^{\circ} 10^{\prime} 44^{\prime \prime} \mathrm{N} / 108^{\circ} 40^{\prime} 44^{\prime \prime} \mathrm{E}, \mathrm{h}=1400-1600 \mathrm{~m}$, 30.IV.2009, leg. D.Fedorenko'.

DESCRIPTION. Very similar to the previous species except as follows: BL 3.5-3.7 mm, body (Fig. 5) very shiny, elytral spots smaller, extending from middle to $4 / 5$ elytra. Labrum and elytral base with distinct microsculpture, otherwise dorsal microsculpture missing, being very superficial on clypeus, anterior part of frons, and neck; elytral aciculate microsculpture outside and partly including glabrous submarginal area. Pronotum glabrous except a few setae along apex.

Head: neck constriction moderately deep, vertex moderately convex, Supra-ocular carina very fine above eye, obliterate before and behind, hardly separable from dense longitudinal wrinkles on each side; genae nearly even and straight. Labrum truncate apically. Antennomeres 5-10 barely transverse, nearly as long as wide.

Pronotum: PW/PL 1.50-1.57, PW/HW 1.06-1.14, PLw/ PL $0.21-0.25$, PB/PA 0.88-0.93, sides sinuate behind apical angles, sides of base subsinuate; apex sinuate; lateral edge nearly smooth, with 1-2 subtle denticles before almost right basal angles.

Elytra longer and barely dilated apicad, EL/EW 1.421.45, EW/PW 1.67-1.77; sides slightly and evenly rounded. USS consisting of $11-12+4+5$ setae.

Legs. Mesotarsomere 1 distinctly longer than mesotarsomere 5 while distinctly shorter than mesotarsomeres 2-4 combined, TF2 1.17-1.33: 1.36-1.50; TF3 1.54-1.86 : $1.46-1.71$

Aedeagus (Figs 24-25, 29, 41-42): median lobe large, with apex toothed; right paramere distinctly longer than the left one, being in form of a straight razor. Internal sac with large spiniform apical sclerites.

DIAGNOSIS. Distinctive from E. posteroguttata sp.n. chiefly in having much less convex vertex, glabrous pronotum, smaller elytral spots, and less distinct dorsal microsculpture, in addition to very distinctive aedeagus.

DISTRIBUTION. Known from two localities in the Dalat Plateau, Southern Vietnam.

NAME. Toponymic, referring to the type locality of the species.

HABITATS AND HABITS. As described for the genus, except at higher elevations.

\section{Eustra csikii Jedlička, 1968}

Figs 6, 13-15, 30, 37-38.

Jedlička, 1968: 294 ('Vietnam: Prov. Ninh-Binh'); Deuve, 2001: 564, 573 (Cuc Phuong Nat. Res. as exact type locality).

MATERIAL. $160^{7} \sigma^{7}, 7$ O 9 (SIEE), Northern Vietnam, Phu Tho Province, $\sim 90 \mathrm{~km}$ W of Hanoi, Xuan Son National Park, $21^{\circ} 07^{\prime} 01^{\prime \prime} \mathrm{N}$ 104'56'39"'E, h=400-700 m, 6-15.VI.2014, D.Fedorenko leg.; $150^{\top} 0^{\top}, 7$, $\circ+$ (SIEE), same data except $21^{\circ} 06^{\prime} 39^{\prime \prime} \mathrm{N} 104^{\circ} 57^{\prime} 25^{\prime \prime} \mathrm{E}$, $\mathrm{h}=400 \mathrm{~m}$.

REDESCRIPTION. Very similar to the previous species except as follows: BL 2.95-3.35 mm, body (Fig. 6) pale brown, frons, vertex and neck dark brown to black (sometimes frons and vertex reddish-brown), elytra more infuscated due chiefly to ground colour slightly darker, brown, in couple with dark spots larger, almost reaching lateral margin and apex, narrowly separated along suture, and extended to basal 1/4-2/5. Dorsal microsculpture coarse on labrum and neck, superficial on clypeus, hardly traceable to obliterate on frons (except anteriorly), vertex, pronotum and elytra. Elytral aciculate microsculpture entirely or partly within and outside glabrous submarginal area. Head moderately densely pubescent, pronotum sparsely pubescent to nearly glabrous.

Head with neck constriction deep and vertex moderately convex, mostly bicarinate on each side, i.e., with supra-antennal carina and supra-ocular one running close to each other, the former reaching posterior margin of eye or almost so while the latter starting above antennal insertion, declining towards and disappearing on gena. Labrum apically evenly convex.

Pronotum barely longer, PW/PL 1.48-1.61 (1.55, $\mathrm{n}=5)$, PW/HW 1.10-1.13 (1.11), PLw/PL 0.21-0.26 (0.24, $\mathrm{n}=6)$, PB/PA $0.83-0.90$ (0.87), sides mostly subsinuate in front of obtuse basal angles; apex slightly to deeply sinuate. Basal foveae rounded, large and deep, each extended apicad into a submarginal line or not. Explanate lateral margin from narrow and reflexed to wide and little reflexed in the case of shallower or deeper submarginal line, respectively; lateral edge minutely yet distinctly tuberculate or denticulate, more so in basal half.

Elytra shorter, EL/EW 1.32-1.38 (1.36, n=5), EW/PW $1.59-1.69$ (1.67). USS consisting of $11-13+5+5$ setae.

Legs. Mesotarsomere 1 slightly shorter than mesotarsomeres 2-4 combined and distinctly longer than mesotarsomere 5, TF2 0.92-1.18 (1.06) : 1.17-1.27 (1.20); TF3 $1.43-1.70$ (1.57) : 1.32-1.51 (1.38).

Aedeagus (Figs 13-15, 30, 37-38): median lobe with apex toothed; right paramere as long as left one, broadened apically. Internal sac with large apical sclerites.

DIAGNOSIS. The species has very distinctive colour pattern and aedeagus.

DISTRIBUTION. Hitherto known from two localities in Northern Vietnam.

HABITATS AND HABITS. See for the genus.

\section{Eustra nageli subglabra Fedorenko, ssp.n.} Figs 4, 19-21, 26, 43-44.

MATERIAL. Holotype $0^{7}$ (ZMMU) labelled: 'S Vietnam, N Dongnai [=Dong Nai] Pr[ovince]., Nam Cat Tien Nat. Park, Exped.Russ.-Vietnamese, Tropical Centre, W[indow]T[rap]-3, 19.V.-18.VI.2005, leg. D.Fedorenko'. Paratypes (SIEE): $O^{\top}, 2+9$, same data; $\sigma^{2}$, same data except WT-4; + , same data except WT-5, 20.V.-; O', 5오, 'Vietnam, Binh Phuoc Prov[ince]., Bu Gia Map Nat. Park, $12^{\circ} 11^{\prime} 37^{\prime \prime} \mathrm{N} / 107^{\circ} 12^{\prime} 21^{\prime \prime} \mathrm{E}, \mathrm{h}=350-540 \mathrm{~m}, 16-$ 17.IV.2009, leg. D. Fedorenko'

DESCRIPTION. Body (Fig. 4) rather large and robust, BL 3.4-3.7 mm, shiny pale brown, elytra slightly dull in female; each elytron with a rounded to subquadrate spot between middle and 3/4 elytra; the spots widely separated 
along suture and not reaching lateral margin. Dorsal microsculpture superficial on labrum, clypeus and neck, hardly traceable to obliterate on frons and vertex, almost indistinct to obliterate on pronotum. Elytral microsculpture almost indistinct to obliterate in male, very distinct in female; aciculate microsculpture along sides almost imperceptible in male, very fine in female. Head and pronotum sparsely pubescent, elytra moderately densely pubescent and faintly tuberculate; pubescence very short, on disc about half as long as distance between neighbouring two setae in longitudinal row.

Head with neck constriction imperceptible or traceable on sides only, vertex flat. Supra-ocular carina fine, mostly distinct medially and obliterate before and behind, sometimes quite otherwise. Frontoclypeal suture slightly concave. Labrum truncate apically, minutely emarginate between inner two pairs of setae. Antennomeres 5-10 increasingly yet slightly transverse. Mandibular scrobe bisetose.

Pronotum cordate, two thirds wider than long, PW/PL 1.55-1.72 (1.65, n=5), PW/HW 1.15-1.22 (1.18), broadest a fifth from apex, PLw/PL 0.19-0.24 $(0.22, \mathrm{n}=6)$, sides distinctly sinuate in front of basal angles, almost indistinctly sinuate just behind apical angles. Base barely narrower than apex, PB/PA 0.86-0.91 (0.88), its sides sinuate or subsinuate, basal angles sharp, subrectangular to obtuse; apex deeply sinuate. Basal foveae round and deep, each extended forward into a more or less distinct submarginal line or the latter isolated. Lateral margin rather narrowly explanate and, along with basal angles, very slightly reflexed in basal half, more widely explanate in apical half; lateral bead very fine, strongly reflexed, disappearing just in front of basal angle. Lateral edge minutely denticulate or tuberculate, more distinctly so in basal half, with 11-13 denticles traceable in total. Basal bead missing or laterally imperceptible.

Elytra short and wide, EL/EW 1.26-1.31 (1.28, n=5), EW/PW 1.68-1.82 (1.74), broadened slightly apicad; base very slightly oblique towards peduncle, humeri rounded at apex, sides rounded. USS consisting of $10-13+5+5$ setae. Submarginal glabrous area large.

Legs. Mesotarsomere 1 longer than mesotarsomeres 24 combined and distinctly longer than mesotarsomere 5, TF2 1.34-1.54 (1.40) : 1.12-1.38 (1.23); metatarsomere 1 a third longer than metatarsomeres 2-4 combined and much longer than mesotarsomere 5, TF3 1.63-1.80 (1.73) : 1.251.39 (1.34)

Aedeagus (Figs 19-21, 26, 43-44) large, with very wide obtrapezoidal apex; right paramere clavate, slightly longer

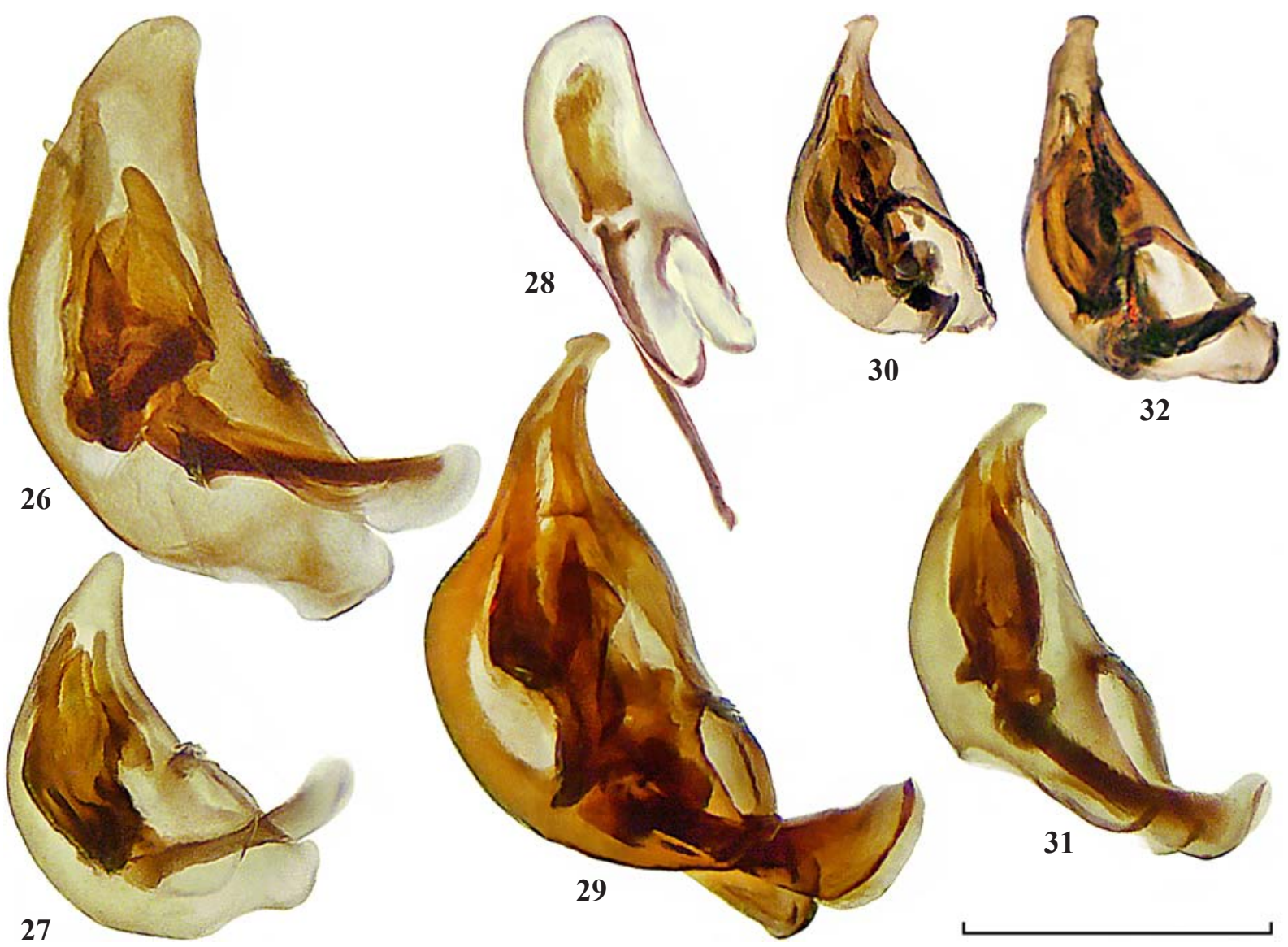

Figs 26-32. Median lobe of aedeagus in plane of apex ( left ventrobasal aspect): 26 - Eustra nageli subglabra ssp.n.; 27 - E. posteroguttata sp.n.; $28-$ E. cariniceps sp.n.; $29-$ E. dalatensis sp.n.; $30-$ E. csikii; $31-$ E. parallela; $32-$ E. matanga matanga Scale bar $0.5 \mathrm{~mm}$.

Рис. 26-32. Средняя доля эдеагуса в плоскости вершины ( вентробазально слева): 26 — Eustra nageli subglabra ssp.n.; 27 - E. posteroguttata sp.n.; $28-$ E. cariniceps sp.n.; $29-$ E. dalatensis sp.n.; $30-$ E. csikii; $31-$ E. parallela; $32-$ E. matanga matanga Масштаб 0.5 мм. 
than left one. Internal sac with large, spiniform, apical sclerites, including large subtriangular sclerite and a very slender dorsal one having apex somewhat hooked.

DIAGNOSIS. Distinctive from E. nageli nageli Deuve, 2005 from Nepal chiefly in having very short and sparse dorsal pubescence, aedeagus apex barely shorter, and the dorsal sclerite of the internal sac of aedeagus being less curved apically.

DISTRIBUTION. Southern Vietnam.

NAME. Refers to the subglabrous body dorsum.

HABITATS AND HABITS. Six of totally seven specimens of the type series were collected in window traps in a tropical monsoon forest. One specimen from the Bu Gia Map National Park was taken by hands under bark of a large standing dead tree, together with specimens of E. cariniceps sp.n. and E. posteroguttata sp.n.

COMMENTS. Dr. Th. Deuve (MNHM) was kind enough to compare aedeagus of the holotype of E. nageli with my digital images of aedeagus of E. nageli subglabra ssp.n. He [pers. communication] guessed genitalic differences between the two taxa to be of subspecific level. I share his point of wiew, with reservation that $E$. nageli subglabra ssp.n. may be close yet separate species, which surmise is additionally based on a very wide spatial gap between the ranges of the two taxa.

\section{Eustra parallela Fedorenko, sp.n.}

Figs 1, 16-18, 31, 45-46.

MATERIAL. Holotype $\sigma^{7}$ (ZMMU, formerly kept at MPSU) with label: 'E Malaysia, Sabah, Mt. Kinabalu N. P., 1700m, 1630.07.[20]02, Kurbatov \& Zimina'.

REDESCRIPTION. BL $3.4 \mathrm{~mm}$, body (Fig. 1) shiny pale brown, elytra each with a cloudy brown spot extending from $2 / 3$ to $3 / 4$ elytra; the spots widely separated from both each other and lateral margin. Dorsal microsculpture distinct on labrum, imperceptible on clypeus, obliterate behind, including pronotum and elytra; elytral aciculate microsculpture outside and including greater part of glabrous submarginal area. Head moderately densely pubescent only laterally, widely glabrous medially, pronotum glabrous except very few setae in apical third; elytra very sparsely pubescent on disc, more densely along base and behind humeri; pilosity moderately long, discal setae half as long as distance between neighbouring two in a longitudinal row or barely longer; setigerous punctures indistinctly tuberculate on disc.

Head with neck constriction shallow laterally and nearly imperceptible medially, vertex almost flat. Supra-ocular carina conspicuous above eye, obliterate behind, leaving genae even and straight. Frontoclypeal suture very gently concave. Labrum apically truncate, with 6 close setigerous tubercles. Antennomeres 5-10 increasingly transverse, about as long as
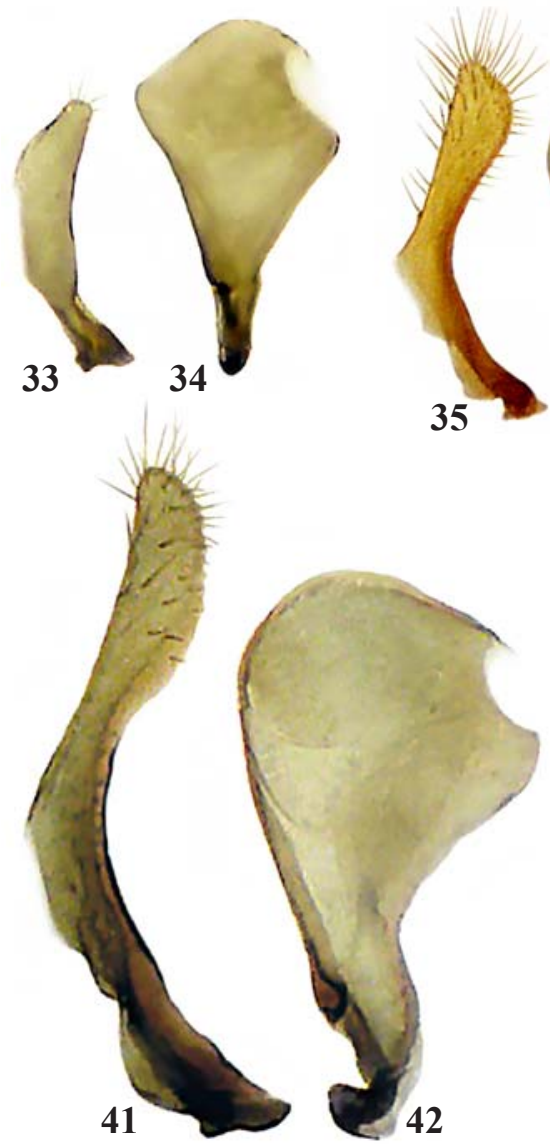
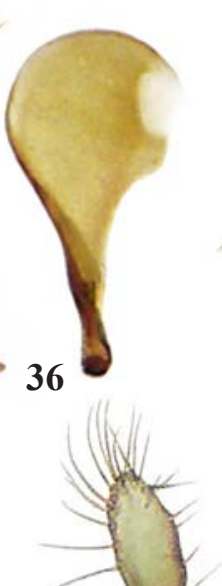

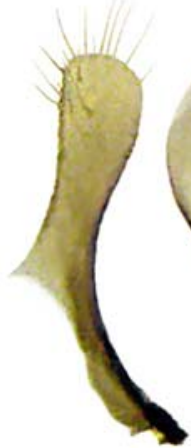

37

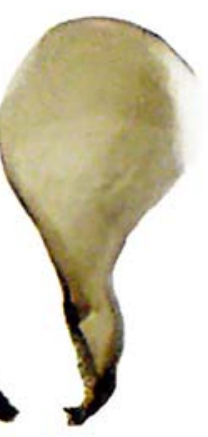

38
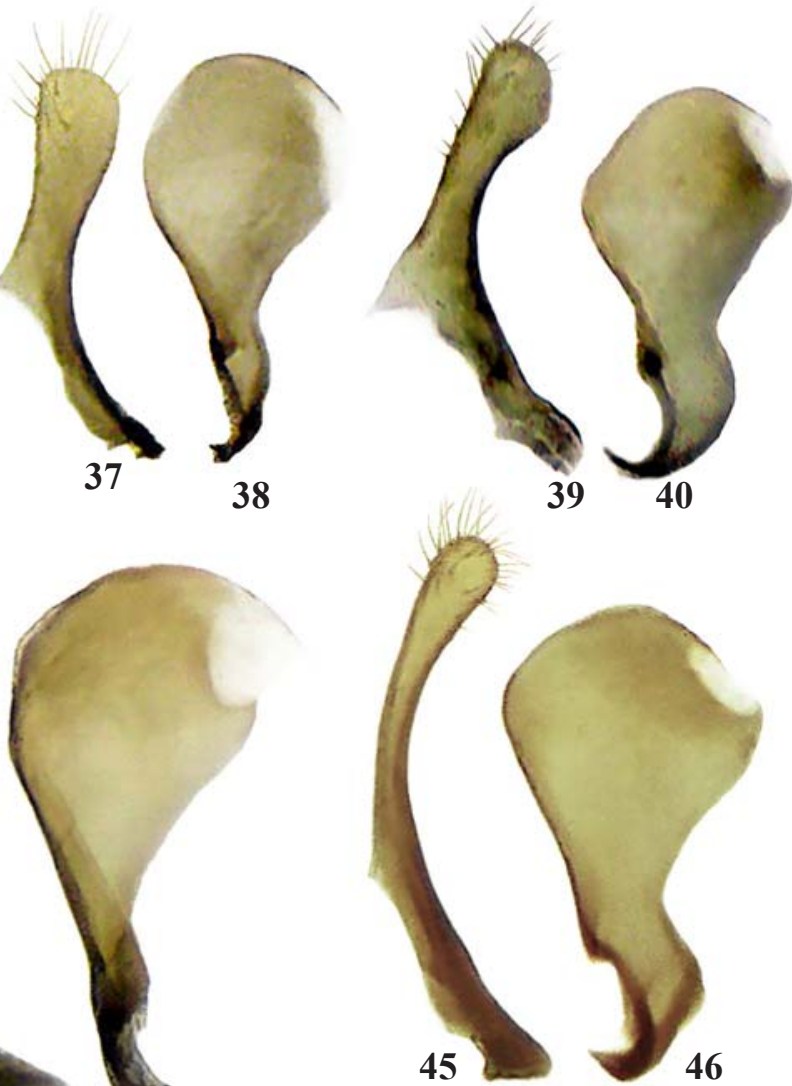

43

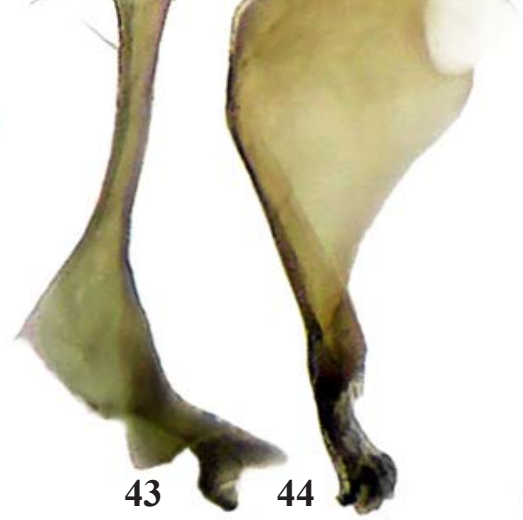

Figs 33-46. Parameres: 33-34-Eustra cariniceps sp.n.; 35-36-E. matanga matanga; 37-38 - E. csikii; 39-40-E. posteroguttata sp.n.; 41-42 - E. dalatensis sp.n.; 43-44-E. nageli subglabra ssp.n.; 45-46-E. parallela sp.n.; 33, 35, 37, 39, 41, 43, 45 - right paramere, left aspect; 34, 36, 38, 40, 42, 44, 46 - left paramere, right aspect. Scale bar $0.5 \mathrm{~mm}$.

Рис. 33-46. Парамеры: 33-34 - Eustra cariniceps sp.n.; 35-36 - E. matanga matanga; 37-38 - E. csikii; 39-40 - E. posteroguttata sp.n.; 41-42 - E. dalatensis sp.n.; 43-44-E. nageli subglabra ssp.n.; 45-46 - E. parallela sp.n.; 33, 35, 37, 39, 41, 43, 45 - правая парамера, вид слева; $34,36,38,40,42,44,46$ - левая парамера, вид справа. Масштаб 0.5 мм. 
wide, with only 9 and 10 distinctly transverse. Mandibular scrobe bisetose.

Pronotum cordate, PW/PL 1.59, PW/HW 1.12, PLw/PL 0.28 , sides sinuate in front of right and sharp basal angles, subsinuate behind apical angles. Base barely narrower than apex, PB/PA 0.92, its sides slightly oblique and sinuate; apex rather deeply concave. Basal foveae round, large and deep, each extended apicad into a deep submarginal lines almost reaching apex. Lateral margin widely explanate and slightly reflexed outside this line in apical half, more reflexed behind; lateral bead strongly reflexed; lateral edge with 8-9 minute denticles or tubercles. Basal bead fine to missing. Median line and anterior transverse impression deep, basal transverse impression very deep.

Elytra long, EL/EW 1.49, EW/PW 1.61, nearly parallelsided in middle third; base slightly oblique towards peduncle, humeri rounded apically. Lateral edge setulose yet smooth. Submarginal glabrous area rather large. USS consisting of $12+5+5$ setae.

Legs. Mesotarsomere 1 distinctly shorter than mesotarsomeres 2-4 combined and slightly shorter than mesotarsomere 5 (TF2 $0.92: 1.18$ ); metatarsomere 1 distinctly longer than metatarsomeres 2-4 combined and mesotarsomere 5 (TF3 $1.38: 1.13$ ).

Aedeagus (Figs 16-18, 31, 45-46): apex of median lobe toothed, right paramere slender, clavate, and longer than left one. Internal sac with several, large, spiniform, apical sclerites, including smaller dorsal ones in couple with large and arcuate ventral sclerite.

DIAGNOSIS. The new species is recognizable chiefly in the combination of almost flat vertex before very shallow neck constriction, fairly long elytra with very sparse elytral pubescence, combined with a distinctive aedeagus. This latter is different from that of E. m. matanga in the following points: right paramere very slender and subclavate, base of median lobe (that within its laterobasal extensions) as long as apical part (vs. distinctly shorter), and internal sac with apical sclerites different in shape.

DISTRIBUTION. Known from the type locality only.

HABITATS AND HABITS. No data.

\section{Eustra matanga matanga Andrewes, 1919} Figs 7-9, 32, 35-36.

Andrewes, 1919: 299 (Sarawak, Borneo); 1933: 348; Deuve, 2001: $565,571$.

MATERIAL. $20^{7} O^{7}, 9$ (SIEE) labelled: Bali Island, near Tamblingan Lake, $8^{\circ} 15^{\prime} \mathrm{S} / 115^{\circ} 06^{\prime} \mathrm{E}, \mathrm{h}=1200 \mathrm{~m}, 22-24 . \mathrm{XI} .2018$, leg. D. Fominykh.

DISTRIBUTION. Borneo, Sumatra and Java; first recorded in Bali. The other two subspecies, E. m. darlingtoni Deuve, 2001 and E. m. negrosensis Deuve, 2001 are confined to the Philippine islands Luzon or Negros, respectively.

HABITATS AND HABITS. No data.

COMMENTS. Eustra matanga is currently recognized as a widespread oligotypic species that includes three subspecies, each defined by a distinctive right paramere, with E. $m$. darlingtoni being additionally different in a paler body.

The specimens listed belong to the nominotypical subspecies and they are very similar and very close to $E$. posteroguttata sp.n. Additional small differences are as follows: BL 3.25-3.4 mm, body shiny pale brown, elytra each with an ill-defined to vague darker spot spanning $2 / 5$ to $3 / 4$ elytra; these spots widely separated from both each other and narrowly separated from reflexed lateral margins. Dorsal micro- sculpture distinct on on labrum, hardly taraceable on clypeus, otherwise missing; elytral aciculate microsculpture outside and partly including glabrous submarginal area. PW/PL 1.551.62 (1.59, n=3), PW/HW 1.12-1.15 (1.13), PLw/PL 0.28, sides sinuate in front of obtuse and sharp basal angles, subsinuate behind apical angles. Base barely narrower than apex, PB/PA 0.89-0.93 (0.91). Lateral edge a bit more distinctly crenate, with 7-10 minute. Elytra slightly longer, EL/ EW 1.37-1.44 (1.42), EW/PW 1.63-1.74 (1.70). Mesotarsomeres 1 and 5 shorter (TF2 $1.10: 1.40, \mathrm{n}=2)$ ) TF3 1.73$1.82: 1.36$.

Aedeagus (Figs 7-9, 32, 35-36) similar to those of $E$. csikii and E. posteroguttata sp.n.: apex of median lobe toothed, right paramere subclavate, as long as left one, with apex obliquely truncate ( $v s$. rounded in the two similar species). Internal sac with distinctive armature consisting of a cluster of a few apical sclerites.

Acknowledgements. I am very indebted to A. Taghavian (MNHM) and Dr. K.V. Makarov (MPSU) for the loan of material under their care and to D. Fominykh (Moscow) for donating specimens. I extend my cordial thanks to Dr. Th. Deuve for his kind answers to my questions about the holotype of $E$. nageli. This study was funded by the Presidium of the Russian academy of sciences, Program No 41 'Biodiversity of natural systems and biological resources of Russia'.

\section{References}

Andrewes H.E. 1919. Papers on Oriental Carabidae. - III // Ann. Mag. Nat. Hist. Ser.9. Vol.4. P.290-300.

Andrewes H.E. 1929. The fauna of British India, including Ceylon and Burma. Coleoptera. Carabidae. Vol. I.-Carabinae. London: Taylor \& Francis. XV+430 p.

Andrewes H.E. 1933. A Catalogue of the Carabidae of Sumatra // Tidschr. Entomol. Jg.76. S. 319-382.

Bänninger M. 1927. Monographie der Subtribus Scaritina (Col. Carab.) I, II. // D. Entomol. Zeitschr. 1927. H.3. S.177-216.

Bänninger M. 1949. Ueber Carabinae (Col.) Ergänzungen und Berichtigungen III, mit Bemerkungen zu R.Jeannels neuer Einteilung der Carabiden // Mitt. Munch. Ent. Ges. Jg.35-39 (19451949). S.127-157.

Bates H.W. 1892. Viaggio di Leonardo Fea in Birmania e regione vicine. XLIV. List of the Carabidae // Ann. Mus. Stor. Nat. Genova. Ser. 2. Vol. 12 (32). P. 267-428.

Chaudoir M. 1854. Mémoire sur la Famille des Carabiques. 4e partie // Bull. Soc. Nat. Mosc. T.27. P.279-352.

Chaudoir M. 1868. Révision du Groupe de Ozaenides // Ann. Soc. Ent. Belg. T.11. P.43-74.

Deuve Th. 1986. Ozaeninae cavernicoles de Thailande: diagnoses préliminaires (Coleoptera, Paussidae) // Rev. Franç. d'Entomol., N.S. Vol.8. P.161.

Deuve Th. 1996. Description d'un coléoptère troglobie du genre Eustra, découvert dans un karst du Vietnam méridional (Paussidae) // Rev. Franç. d'Entomol., N.S. Vol.18. P.23-26.

Deuve Th. 2001. Le genre Eustra Schmidt-Goebel, 1846, insectes (Coleoptera, Paussidae, Ozaeninae) à genitalia femelles orthotopiques // Zoosystema. V.23. P.547-578.

Deuve Th. 2002. Une nouvelle Eustra troglobite du karst de Maros, Sulawesi (Coleoptera, Paussidae) // Nouv. Rev. d'Entomol. Vol.19. No.2. P.193-195.

Deuve Th. 2005. Nouveaux Ozaeninae (Eustrini et Ozaenini) de la région Neotropicale et du Népal (Coleoptera, Caraboidea, Paussidae) // Rev. Franc. d'Entomol., N.S. Vol.27. P.103-116.

Faille A. 2010. Les Coléoptères troglobites de l'île de Sulavesi (Indonésie); descriptions du mâle du Paussidae cavernicole Eustra saripaensis Deuve, 2002 (Coleoptera) // Bull. Soc. Ent. Fr. Vol.115. No.3. P.375-380. 
Gueorguiev B.V. 2014. Eustra petrovi sp.nov. - first record of a troglobitic Ozaenini from China (Coleoptera: Carabidae: Paussinae) // J. Insect Biodiversity. Vol.2. No.2. P.1-9.

Jeannel R. 1946. Faune de l'Empire Français VI. Coléoptères Carabiques de la region Malgache (première rartie). Paris. P.1-372. Jedlička A. 1968. Neue Carabiden aus der palaearktischen Region (Coleoptera, Carabidae) // Reichenbachia. Bd.8. Nr.34. S.285296.

Moore W. 2008. Phylogeny of the Western Hemisphere Ozaenin (Coleoptera: Carabidae: Paussinae) based on DNA sequence data // Ann. Carnegi Mus. Vol.77. No.1. P.79-92.

Moore W., Song X. Di Giulio A. 2011. The larva of Eustra (Coleoptera, Paussinae, Ozaenini): a facultative associate of ants // Zookeys. Vol.90. P.63-82.

Nagel P. 2018. Flanged Bombardier Beetles of Nepal (Insecta: Coleoptera: Carabidae: Paussinae), with nomenclatural and taxonomic notes and descriptions of new species // Hartmann M., Barclay M. \& Weipert J. Biodiversität und Naturausstattung im Himalaya VI. Erfurt. S.249-282.

Schmidt-Göbel H.M. 1846. Faunula Coleopterorum Birmaniae, adjectis nonnulis Bengaliae indigenis. P.I-VIII, 1-94, P1.I-III.

Song X.-B., Tang L., Peng Zh. 2018. Flanged Bombardier beetles from Shanghai, China, with description of a new species in the genus Eustra Schmidt-Goebel (Coleoptera, Carabidae, Paussinae) // Zookeys. Vol.740. P.45-57.

Stork N.E. 1985. Dhanya, a South-east Asian genus of ozaenine ground beetles // J. Nat. Hist. Vol.19. P.1113-1138.

Terada K., Yeh L.-W., Wu W. 2013. Notes on Taiwanese Caraboidea (Coleoptera) III. Rediscovery of Eustra chinensis Bänninger (Paussinae: Ozaenini) // Collection and Research. Vol.26. P.3136.

Uéno S.-I. 1964. Notes on the carabid beetles from the Amami group of the Ryu-Kyu Islands // Kontyû. Vol.32. No.2. P.249-263.

Uéno S.-I. 1981. A new blind species of the genus Eustra (Coleoptera, Paussidae) from Northern Thailand // Kontyû. Vol.49. No.4. P.620-623. 